It has been decided to revise and re-print four of the series of technical monographs originally published by the Plastics Institute, and $£ 1,000$ has been allocated for this purpose. $£ 200$ has been allocated for the purchase of text-books for the libraries of the local sections of the Institute, with a further special donation of $£ 200$ to establish a library for the newly formed South Wales and Monmouth Section. It has been agreed to allot $£ 1,250$ for the purchase of capital equipment for technical colleges during 1952, and the trustees have asked the Plasties Institute to make specific recommendations concerning the equipment to be purchased and the colleges to benefit.

\section{International Congress of Psychology}

THe International Congress of Psychology will hold its next meeting, in 1954, in Montreal, instead of in New York as previously planned. The American Psychological Association and the Canadian Psychological Association will be joint hosts for the meeting. In making this announcement, the American Psychological Association gives as the main reason "the delays and embarrassments which foreign scientists experience in attempting to obtain even temporary admission to this country". The Internal Security (McCarran) Law is considered to be responsible, and, by its restrictive action, to be damaging the exchange of ideas between the United States and the rest of the world. Some two thousand psychologists are expected to attend the congress in Montreal.

\section{Instruments and Measurements: Conference in Stockholm}

The Royal Swedish Academy of Engineering Sciences (I.V.A.) and the Association of Technical Physicists (T.F.F.) are arranging an "Instruments and Measurements Conference 1952" to be held in Stockholm during September 22-25. The Conference will be organized into the following main groups: methods of measurement in physical chemistry; methods of measurement and control in industry; mechanical methods of measurement and metrology ; methods of measurement in nuclear physics and radioactivity ; and miscellaneous methods of measurement. Symposia will be arranged in the first four groups. The official languages of the Conference will be English, German and French. A preliminary programme, with a list of papers, is now ready. All communications regarding the Conference should be addressed to Yngve Axner, Kungl. Tekniska Högskolan, Stockholm 70. An exhibition of instruments and laboratory equipment will be held in the Exhibition Halls of the St. Eriks Fair during September 23-30, to which members of the Conference will be admitted free of charge. Further information on the exhibition can be obtained from St. EriksMässan, Lidingövägen 10, Stockholm 26.

\section{The Night Sky in August}

Furd moon oceurs on Aug. 5d. 19h. 40m., U.T., and new moon on Aug. 20d. 15h. $20 \mathrm{~m}$. The following conjunctions with the moon take place: Aug. 4d. 18h., Mercury $6 \cdot 4^{\circ}$ S.; Aug. 12d. 17h., Jupiter $7^{\circ}$ S. ; Aug. 19d. 12h., Mercury $4^{\circ}$ S. ; Aug. 22d. 06h., Venus $4^{\circ}$ N. ; Aug. 24d. 15h., Saturn $7^{\circ}$ N.; Aug. 28d. 05h., Mars $3^{\circ}$ N. Mercury is in inferior conjunction on Aug. 12 and cannot be observed during the first part of the month; towards the end of the month it is a morning star, rising at $3 \mathrm{~h} .30 \mathrm{~m}$. on Aug. 31, when its stellar magnitude is 0 . Venus, an evening star, rises at $20 \mathrm{~h}$. $15 \mathrm{~m} ., 19 \mathrm{~h} .55 \mathrm{~m}$., and $19 \mathrm{~h}$.
$25 \mathrm{~m}$. at the beginning, middle and end of the month, respectively, stellar magnitude $-\mathbf{3} \cdot 3$. Mars is an evening star, setting at $22 \mathrm{~h} .30 \mathrm{~m} ., 21 \mathrm{~h} .55 \mathrm{~m}$. and 21h. $15 \mathrm{~m}$. on August 1, 15 and 31, respectively, its stellar magnitude varying from 0 to 0.3 during this period. It is close to $\alpha$ Libræ early in the month and moves eastward until it is a little south of $\beta$ Scorpii at the end of the month. Jupiter rises at $23 \mathrm{~h} ., 22 \mathrm{~h}$. $10 \mathrm{~m}$. and $21 \mathrm{~h} .10 \mathrm{~m}$. on Aug. 1,15 and 31 , respectively, stellar magnitude about -2 . The planet is nearly $3^{\circ}$ south of $\delta$ Arietis during most of August. Saturn is an evening star, setting at $2 \mathrm{lh}$. $50 \mathrm{~m} ., 21 \mathrm{~h} ., 19 \mathrm{~h}$. $55 \mathrm{~m}$. at the beginning, middle and end of the month, respectively, stellar magnitude $\mathbf{l} \cdot \mathbf{l}$. It moves from a position close to $\gamma$ Virginis to north of $\theta$ Virginis during August. The Perseid meteors will be active during the month, the maximum of the shower occurring about August 10-12.

There will be a partial eclipse of the moon on Aug. 5, partly visible at Greenwich. The circumstances of the eclipse are as follows:

$\begin{array}{lcccc}\text { Moon enters penumbra } & \text { Aug. } & 5 \mathrm{~d} . & \mathbf{1 7 h} . & \mathbf{2 6} \cdot 6 \mathrm{~m} . \\ \text { Moon enters umbra } & 5 & 18 & 33.4 \\ \text { Middle of the eclipse } & 5 & 19 & \mathbf{4 7 \cdot 4} \\ \text { Moon leaves umbra } & 5 & 21 & 01.4 \\ \text { Moon leaves penumbra } & & 5 & 22 & 08.2\end{array}$

The magnitude of eclipse is $0 \cdot 538$, the moon's diameter being 1.0. An annular eclipse of the sun on August 20 is invisible at Greenwich. It will be visible over portions of South America.

\section{Announcements}

THE following appointments have been announced by the University of Sheffield: F. T. Williams, lecturer in the Postgraduate School of Mining; B. R. Pursall, lecturer in the Department of Mining; P. H. Price (at present research assistant to the professor of fuel technology) to be lecturer in fuel technology ; R. G. Siddall, research assistant to the professor of fuel technology ; E. H. Gillespie, honorary lecturer in bacteriology. Dr. B. Donovan, lecturer in physics, has resigned on appointment as senior lecturer in physics at the Northern Polytechnic, London.

THE Research Fund of the Chemical Society provides grants for the assistance of research in all branches of chemistry. About $£ 700$ per annum is available for this purpose, the income being derived from a donation of the Worshipful Company of Goldsmiths, from the Perkin Memorial Fund, and from other sources. Applications for grants should be submitted to the General Secretary, The Chemical Society, Burlington House, Piccadilly, London, W.1, on the appropriate form not later than November 15, 1952 .

ThE American Embassy and the United States Educational Commission in the United Kingdom announce a programme of grants to assist senior British scholars to lecture or carry out research in the universities of the United States. The grants will be paid in dollars, and they will be tenable for the academic year 1953-54; the monthly stipend will not be more than 270 dollars. Applicants must be citizens of the United Kingdom or Colonies, and should have a plan for research which can be effectively carried out in the time they propose to spend in the United States; they must arrange their own affiliation with a university in the United States. Application forms, to be returned before November 15 , can be obtained from the Assistant Cultural Relations Officer, Room 302, 41 Grosvenor Square, London, W.1. 